\title{
Lin_Supplemental FigS2
}

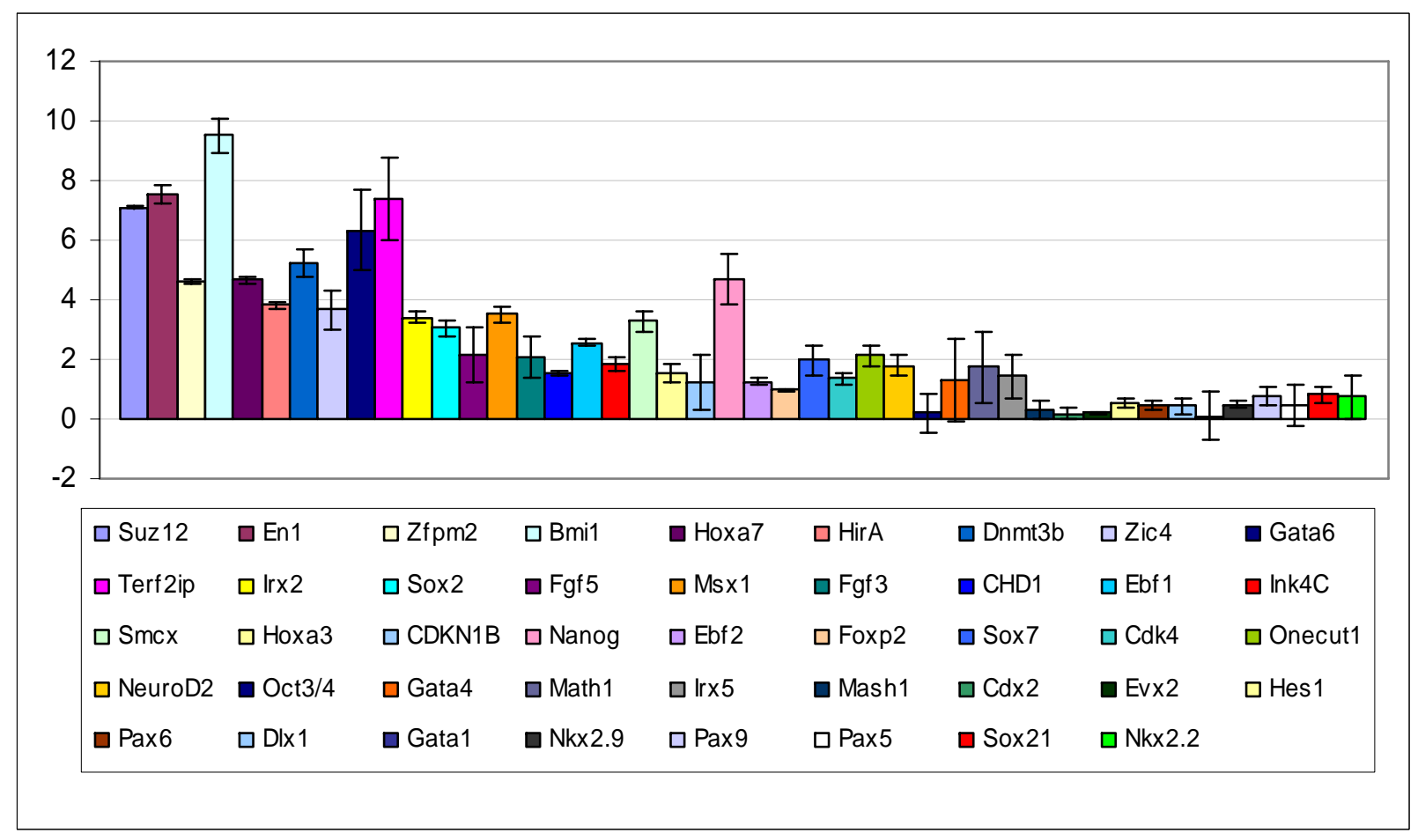

